\title{
Flaked Material
}

National Cancer Institute

\section{Source}

National Cancer Institute. Flaked Material. NCI Thesaurus. Code C63141.

Problem associated with the detachment of small pieces of the coating film of a material. 